\title{
Żydowska społeczność Białegostoku u schyłku swego istnienia (1950-1970)
}

W dzisiejszym Białymstoku nie ma społeczności żydowskiej, śladów żydowskiej dzielnicy ani powszechnej świadomości, iż do drugiej wojny światowej społeczność ta stanowiła bardzo dużą część ludności miasta (43\% w 1936 r. i aż dwie trzecie pod koniec XIX w. $\left.{ }^{1}\right)$. Przypominają o niej jedynie tablice Szlaku Dziedzictwa Żydowskiego, parę zachowanych detali architektonicznych, oddalony od centrum, powoli restaurowany cmentarz, kilka nazw ulic, tablic pamiątkowych i niewielkich pomników. Wydaje się, że organizowane co jakiś czas imprezy poświęcone kulturze żydowskiej zaskakują część białostoczan, nieznających historii.

Przyczyny takiego stanu rzeczy są częściowo oczywiste - w Holokauście zginęło sześciu na siedmiu z białostockich Żydów, a zabudowa miasta została w znacznym stopniu zniszczona ${ }^{2}$. Drugi czynnik to powojenne decyzje - spośród ocalałych wielu nie wróciło nigdy do miasta, inni potem je opuszczali stopniowo, wyjeżdżając za granicę lub przeprowadzając się do miast centralnej i zachodniej Polski. Oczywiście miał na to wpływ klimat polityczny i społeczny. On też wpływał na zacieranie śladów żydowskiej obecności w Białymstoku, których nie miał już kto chronić. Po szoku wojny i Holokaustu procesy te zachodziły stopniowo, a przez to mało zauważalnie. Celem tego tekstu jest przedstawienie ostatnich ich etapów - ubywania ludzi, wygasania działalności instytucji, likwidacji pozostałości architektonicznych. Za cezurę początkową przyjęty jest tu, dość nietypowo jak na periodyzację powojennej historii Polski, rok 1950 r., przy czym nie chodzi tu o wyodrębnienie pełnych kalendarzowych dekad, ale wskazanie wyraźnych etapów w życiu społeczności żydowskiej. Lata bezpośrednio powojenne to okres, gdy próbując się zorientować w nowej, dopiero tworzonej rzeczywistości, polscy Żydzi byli rozdarci między chęcią ucieczki z tragicznego dla nich

\footnotetext{
1 Historia Białegostoku, red. A. Dobroński, Białystok 2012, s. 284, 345.

2 D. Boćkowski, E. Rogalewska, J. Sadowska, Kres świata białostockich Żydów, Białystok 2013, s. 56.
} 
miejsca a nadziejami na możliwość odbudowy choćby namiastki przedwojennego życia. Wydawało się to możliwe dzięki polityce władz, które na jakiś czas nadały Żydom, jako jedynej z mniejszości, elementy autonomii. Mieli więc prawo do własnych organizacji społecznych, w tym partii politycznych, działań samopomocowych, kulturalnych, przedsięwzięć gospodarczych itp. Prawo było coraz słabiej wykorzystywane ze względu na kolejne fale migracji i wraz z umacnianiem się stalinizmu - stopniowo ograniczane. Umowny koniec etapu względnej autonomii przyniósł właśnie rok 1950, gdy likwidacji uległ Centralny Komitet Żydów w Polsce, a z nim - wojewódzkie Komitety Żydowskie, które były głównym reprezentantem i organizatorem życia żydowskiego w Polsce. Do tego czasu zakazano działalności wszystkich żydowskich partii politycznych, zlikwidowano struktury żydowskie wewnątrz PZPR. Był to także rok kolejnej fali odpływów ludzi z Polski. Ewidentnie więc zaczął się okres schyłkowy, czego nie zatrzymała zmiana polityczna 1956 r., a przyspieszył rok 1968. Dekady lat pięćdziesiątych i sześćdziesiątych to coraz słabsze próby przetrwania, zachowywania choć elementów tradycji i pamięci. Lata siedemdziesiąte i osiemdziesiąte to już tylko pojedynczy ludzie. Wydarzenia i procesy lat 1950-1989 są bardzo trudne do odtworzenia - nie budziły szerszego zainteresowania z zewnątrz, spoza społeczności żydowskiej, nie miały poważnej obudowy instytucjonalnej, która skutkowałaby pozostawieniem licznych dokumentów. Nie ma od kogo zbierać świadectw. Pozostaje więc wykorzystywanie nielicznych, fragmentarycznych źródeł i wplatanie ich w ogólną wiedzę o przeszłości kraju i miasta. Dotychczas o powojennej społeczności Białegostoku pisała w ograniczonym zakresie Rebecca Kobrin w książce Żydowski Białystok i jego diaspora, wydanej po polsku w 2014, a wcześniej po angielsku w 2010 r.; Anna Pyżewska w artykule o Towarzystwie Społeczno-Kulturalnym Żydów oraz autorka tego tekstu w przygotowanej wspólnie z Ewą Rogalewską i Danielem Boćkowskim pracy Kres świata białostockich Żydów oraz opublikowanym w „Kwartalniku Historii Żydów” artykule poświęconym pierwszym latom powojennym ${ }^{3}$. Istnieje piśmiennictwo poświęcone środowiskom białostockich Żydów, którzy opuścili miasto i kraj, ale wspierali jego mieszkańców, a przede wszystkim ciągle podtrzymują pamięć o miejscu swego urodzenia, mają znaczący wkład w utrwalanie historii, publikują księgi pamięci ${ }^{4}$. Temat ten wykracza jednak poza ramy tematyczne niniejszego opracowania.

3 R. Kobrin, Żydowski Białystok i jego diaspora, przekł. A. Musiał, Sejny - Białystok 2014; A. Pyżewska, Towarzystwo Społeczno-Kulturalne Żydów w Biatymstoku (1950-1970), „Biuletyn Historii Pogranicza" 2011, nr 11; D. Boćkowski, E. Rogalewska, J. Sadowska, op. cit.; J. Sadowska, Społeczność żydowska w Białymstoku w latach 1944-1950, „Kwartalnik Historii Żydów” 2015, nr 3, s. 515-531.

4 Por.: http://www.zchor.org/bialystok/toc.htm, dostęp: 15.02.2015; I. Rybal-Rybalowski, Bialystoker Center and Home - 50 years, http://www.zchor.org/bialystok/yizkor13.htm, dostęp: 10.04. 2013; A. Cz. Dobroński, Miasto Białystok w Izraelu, „Białostocczyzna” 1990, nr 2 (18), s. 26-29; R. Kobrin, op. cit., s. 230-268. 
Społeczność żydowska Białegostoku, według informacji przekazywanych do Wojewódzkiej Rady Narodowej w 1951 r., liczyła 165 osób, ale już rok później skurczyła się do $156^{5}$. Trudno w ogóle tę liczbę zestawiać z ponad 43 tysiącami żyjącymi tu przed wojną (i 50 tysiącami ludzi w białostockim getcie w okresie okupacji), ale też była wyraźnie mniejsza niż w okresie tużpowojennym - przy ówczesnym ogromnym ruchu ludności najwięcej osób, bo ponad 1,5 tysiąca, naliczono w połowie 1946 r. ${ }^{6}$ Już wtedy Białystok traktowany był jednak jako miejsce tymczasowego pobytu Żydów, przystanek w drodze dalej, w tym dla tzw. repatriantów zza nowej granicy wschodniej. Powodem były niedostateczne warunki do życia ze względu zniszczenie miasta i brak bezpieczeństwa7. Póki co, starano się je, z myślą o pozostałej garstce, poprawiać. Nowa władza nie pozwoliła na reaktywację gmin żydowskich, ich funkcje częściowo przejęły kongregacje wyznaniowe, częściowo - komitety żydowskie. Wojewódzki Komitet Żydowski w Białymstoku, którego pierwszym przewodniczacym był ocalały z białostockiego getta wybitny działacz Szymon Datner ${ }^{8}$, prowadził w latach czterdziestych szeroką działalność charytatywną (dożywianie, wparcie materialne, opieka zdrowotna, dom noclegowy), a także kulturalną, oświatową. Wsparcie uzyskiwały żydowskie spółdzielnie pracy i małe warsztaty. Użytkowano część zachowanych budynków należących przed wojną do żydowskich instytucji (np. przy ul. Kupieckiej - dziś Malmeda, Waryńskiego i Mińskiej).

5 Żydowski Instytut Historycznych (dalej: ŻIH), Towarzystwo Społeczno-Kulturalne Żydów w Polsce (dalej: TSKŻ), sygn. 325/146, [b.p.], Pismo TSKŻ do WRN w Białymstoku, 5 VI 1951 r.; sygn. 325/147, [b.p.],Wykaz członków TSKŻ w Polsce na rok 1952.

6 ŻIH, Centralny Komitet Żydów w Polsce (dalej: CKŻP), Wydział Ewidencji i Statystyki, sygn. 303/VI/128, k. 20, Żydzi zarejestrowani wg zawodu i płci, czerwiec 1946.

7 ŻIH, CKŻP, Wydział Produktywizacji, 303/XII/111, k. 12-12v., Eliasz Gołomb, Sprawozdanie z pobytu w Białymstoku od dnia 10 IX do 21 IX 1945 r.

8 Szymon Datner (1902-1989), historyk, pedagog. Studiował prawo i administrację na Uniwersytecie Jagiellońskim. W 1927 r. obronił doktorat z filozofii. W 1969 r. uzyskał stopień dr. hab. historii. Przed wojną pracował w szkolnictwie żydowskim (Kraków, Kielce, Pińsk, Białystok). W czasie wojny w getcie białostockim uczestniczył w ruchu oporu, a następnie walczył w żydowskim oddziale partyzanckim. Po wyzwoleniu pracował w białostockim Biuletynie Radiowym oraz w tamtejszej dyrekcji Lasów Państwowych. Był członkiem Wojewódzkiej Rady Narodowej i przewodniczącym Wojewódzkiego Komitetu Żydów w Białymstoku. Od 1946 do 1948 r. przebywał w Palestynie. Po powrocie był do 1953 r. pracownikiem naukowym w Żydowskim Instytucie Historycznym, w latach 1956-1969 - w Głównej Komisji Badania Zbrodni Hitlerowskich w Polsce, a w 1. 1969-1970 był dyrektorem ŻIH. Następnie piastował m.in. funkcję wiceprzewodniczącego Zarządu Żydowskich Gmin Religijnych w Polsce i przewodniczącego Stowarzyszenia ŻIH (1986-1988). Koncentrował się przede wszystkim na badaniu zbrodni Wehrmachtu na jeńcach wojennych, ucieczek $\mathrm{z}$ niewoli niemieckiej oraz walki i zagłady getta białostockiego, http://baza.archiwa.gov.pl/sezam/sezam.php?l=pl\&mode=show\&zespoly_id=104740, dostęp: 10.06.2016. 
Stopniowo Żydzi odpływali jednak z Białegostoku, np. do Warszawy czy Łodzi, czy na Dolny Śląsk, gdzie na zupełnie nowym gruncie próbowano budować społeczność żydowską na nowo, ale przede wszystkim za granicę - do Palestyny (potem państwa Izrael) czy krajów Zachodu. Z tego względu, a także z powodu celowej polityki władz ograniczały działalność, a potem znikały białostockie instytucje żydowskie. Dotyczyło to m.in. Żydowskiej Kongregacji Religijnej, utworzonej w miejsce przedwojennej gminy wyznaniowej, choć mającej dużo węższy zakres działania. Według ogólnopolskiego statutu (niezatwierdzonego przez władze państwowe) zadaniami zarządów kongregacji były m.in.: utrzymywanie synagog, domów modlitwy, łaźni rytualnych, opieka nad cmentarzami, organizacja rabinatu, szkół religijnych, organizowanie dostaw mięsa koszernego, prowadzenie instytucji dobroczynnych 9 . W 1951 r. Żydowska Kongregacja Wyznaniowa w Białymstoku była jedną z 27 w Polsce (w latach czterdziestych istniało ich 80) i według niezbyt starannej statystyki liczyła 212 członków. W innym zestawieniu, sporządzonym w Urzędzie do Spraw Wyznań (UdSW), możemy jednak przeczytać, iż na początku 1953 r. białostocka Kongregacja liczyła tylko 60 wiernych i 3 pracowników, miała pod opieką synagogę, dom modlitwy i cmentarz - jedyny czynny w Białymstoku, przy ul. Wschodniej. Kongregacji przewodniczył Jakub Plut $^{10}$. Utrzymywała się z symbolicznych składek członkowskich oraz środków przekazanych przez organizację samopomocową American Joint Distribution Committee (AJDC lub Joint), wpłacanych na kontrolowane przez UdSW konto, a największym wydatkiem był coroczny wypiek macy. Kongregacja zlikwidowana została w 1954 r. jako uznana przez UdSW za „nieefektywną" ${ }^{11}$.

Likwidacja dotyczyła też instytucji świeckich, żydowską szkołę powszechną w Białymstoku zamknięto już w 1949, a 1 grudnia 1950 r. przestał istnieć WKŻ oraz Żydowskie Towarzystwo Kulturalne, a ich miejsce zajęło Towarzystwo Społeczno-Kulturalne Żydów w Polsce Oddział w Białymstoku [TSKŻ]. Choć nazwy wydają się podobne, zupełnie inny był charakter tych stowarzyszeń. Kontrolowane przez władze TSKŻ było wykonawcą ich antyizraelskiej polityki, np. organizowało akcje antyemigracyjne przedstawiając Izrael w jak najgorszym świetle $^{12}$. Podstawowym zadaniem nowej organizacji było bowiem według jej statutu „włączanie ludności żydowskiej do budownictwa socjalistycznego w Polsce i do ogólnej walki narodu polskiego o pokój i budowę socjalizmu, popularyzowanie w środowisku żydowskim potężnej siły światowego obozu pokoju, kierowniczej

9 G. Berendt, Życie od nowa. Instytucje i organizacje żydowskie (1944-1950), [w:] Następstwa zagłady Żydów. Polska 1944-2010, red. F. Tych, M. Adamczyk-Grabowska, Lublin 2011, s. 199, 30.

10 ŻIH, TSKŻ, sygn. 325/148, [b.p.], [Pismo do TSKŻ], 22 VI 1953 r.

11 K. Urban, Cmentarze żydowskie, synagogi i domy modlitwy $w$ Polsce $w$ latach 1944-1966 (wybór materiałów), Kraków 2006, s. 34.

12 B. Szaynok, Z historia i Moskwa w tle. Polska a Izrael 1944-1968, Warszawa 2007, s. 238. 
roli ZSRR i krajów demokracji ludowej w zwycięskiej walce o pokój i postęp". Znikły zadania (i możliwości działania) o charakterze socjalnym, opiekuńczym, przeprowadzono bowiem upaństwowienie wszystkich instytucji. Pozostała rola kulturalna, ale, co ciekawe, w pierwszej kolejności wymieniano „przyswajanie pracującym Żydom postępowej kultury narodu polskiego”, potem „,zapoznanie społeczeństwa polskiego z osiągnięciami postępowej kultury żydowskiej”, a głównym celem było „zacieśnianie więzów braterskiego współżycia z pracującą ludnością polską. Na dalszym miejscu znalazło się „Zaspokojenie potrzeb kulturalnych ludności żydowskiej przez krzewienie kultury żydowskiej, narodowej w formie, socjalistycznej w treści”. W odniesieniu do upaństwowionych instytucji żydowskich (teatru, szkól, świetlic, domów dziecka) TSKŻ miało występować jedynie w roli dbającego o nie „czynnika społecznego" ${ }^{13}$. W praktyce upolitycznione i odwołujące się do ideologii komunistycznej stowarzyszenie zwalczało religię i wiążącą się z nią tradycję żydowską, co raziło dużą część żydowskiej społeczności ${ }^{14}$. TSKŻ nie cieszyło się też takim jak poprzednik zaufaniem zagranicznych ośrodków żydowskich i przez ich mniejszą hojność dysponowało w 1951 r. środkami ośmiokrotnie niższymi niż CKŻP w 1949 r. ${ }^{15}$

Oddział TSKŻ w Białymstoku ulokował się (po krótkim okresie przy ul. Malmeda) w budynku dawnej synagogi Piaskower Bet Midrasz przy ul. Pięknej, jednej z dwóch nieruchomości, które mu pozostały (drugą był budynek synagogi Cytronów przy ul. Waryńskiego). Pozostałe, przejęte po WKŻ, stowarzyszenie przekazało Zarządowi Nieruchomości Komunalnych, gdyż nie było w stanie ich utrzymywać. Wśród nich były potrzebujące nadzoru cmentarz przy ul. Żabiej, miejsce pamięci Izaaka Malmeda przy ulicy jego imienia oraz plac po Wielkiej Synagodze. W celu pozyskania środków wynajęto część pomieszczeń synagogi przy ul. Pięknej (mieściło się tam kino „Pionier”, później Teatr Lalek „Świerszcz”) ${ }^{16}$.

TSKŻ miało przede wszystkim prowadzić działalność kulturalną, ale wśród jego działaczy, niewątpliwie zweryfikowanych politycznie, zabrakło żydowskich inteligentów, nad czym ubolewano ${ }^{17}$. Trzeba tu zauważyć, iż środowisko białostockich Żydów właściwie pozbawione było elity, a sytuacja ta zaostrzała się

13 Statut Towarzystwa Społeczno-Kulturalnego Żydów, Warszawa 1951, cyt. za: L. Olejnik, Polityka narodowościowa Polski w latach 1944-1960, Łódź 2003, s. 410.

14 S. Bronsztejn, Z dziejów ludności żydowskiej na Dolnym Ślasku po II wojnie światowej, Wrocław 1993, s. 18.

15 E. Mironowicz, Polityka narodowościowa PRL, Białystok 2000, s. 132.

16 ŻIH, TSKŻ, sygn. 325/146, Protokół zdawczo-odbiorczy, 15 stycznia 1951 r.; sygn. 325/146, pismo do WRN w Białymstoku, VI 1951 r.; http://www.sztetl.org.pl/pl/article/bialystok/11,synagogidomy-modlitwy-i-inne/381, boznica-cytronow-ul-warynskiego-24a-/, dostęp: 10.03.2013.

17 ŻIH, TSKŻ, sygn. 325/142, [b.p.], Protokół z posiedzenia Zarządu Oddziału TSKŻ w Białymstoku w dniu 24 II $1958 \mathrm{r}$. 
wraz z wyjazdami kolejnych osób. Już na początku 1948 r. w ankiecie rozsyłanej przez organizację żydowską puste pozostawiono rubryki: adwokaci, nauczyciele i wychowawcy, dziennikarze i literaci, malarze, aktorzy ${ }^{18}$. Wśród białostockiej inteligencji, wówczas nielicznej, były osoby żydowskiego pochodzenia, ale nieuzewnętrzniające swojej autoidentyfikacji, bądź zasymilowane, a przynajmniej wówczas nieaktywne w środowisku. Dlatego, jak pisze Anna Pyżewska, „Pierwszy przewodniczący Oddziału TSKŻ, Abram Osowicki, był z zawodu krawcem. Kolejny - Izaak Pejsachowicz - deklarował, że jest chemikiem, ale nigdzie nie był zatrudniony. Hersz Hakmajer ukończył siedem klas szkoły podstawowej i dwie klasy seminarium nauczycielskiego, a od stycznia 1945 r. do września 1948 r. zatrudniony był $\mathrm{w}$ organach Bezpieczeństwa Publicznego, m.in. na stanowisku kierownika sekcji szkolenia Wydziału Kadr WUBP w Białymstoku (...). Z innych działaczy warto wymienić np. Wolfa Paszko - stolarza, Sendera Petrycera - piekarza, «bohatera» wielu awantur mających miejsce w środowisku białostockich Żydów, Dawida Cygielnickiego - przed wojną aktywnego działacza ruchu komunistycznego"19. Być może można odnieść do nich ogólne uwagi Szyi Bronsztejna dotyczące czołowych działaczy TSKŻ i ich dogmatycznych, a „częstokroć prymitywnych" poglądów politycznych, które zrażały do organizacji ${ }^{20}$. W każdym razie demonstrowali oni swe przywiązanie do ustroju, czego przykładem może być list kondolencyjny po śmierci Stalina adresowany do ambasady radzieckiej: „Wierni idei Wielkiego Stalina, skupieni wokół naszej Polskiej Zjednoczonej Partii Robotniczej i Rządu, czujni wobec wroga klasowego i żydowskich nacjonalistów, ze zdwojonym wysiłkiem, uczciwą i sumienną pracą nad wykonywaniem planów produkcyjnych, przyczynimy się do szybszej realizacji planu 6-letniego - planu dobrobytu, pokoju i socjalizmu"21.

Zgodnie z duchem czasów większości działań nadawano znaczenie polityczne, np. zobowiązanie do przeprowadzenia akcji werbunkowej do TSKŻ podjęto w 1954 r. na cześć II Zjazdu PZPR. Wysłano w teren trzy grupy agitatorskie, z których każda miała przeprowadzić „uświadamiające pogadanki społeczno-polityczne" aż z 48 rodzinami. Wstąpienie do TSKŻ przedstawiano jako konieczność wynikającą z dyrektyw PZPR 22 .

Działania werbunkowe były potrzebne, gdyż białostockie TSKŻ było organizacją nieliczną - na początku lat 50. skupiało 43 osoby (plus 13 z Suwałk).

18 ŻIH, CKŻP, Wydział Ewidencji i Statystyki, sygn. 303/VI/135, k. 87, Żydzi rejestrowani w miesiącu styczniu 1948 według zawodu i płci.

19 A. Pyżewska, op. cit., s. 90.

20 S. Bronsztejn, op. cit., s. 18.

21 ŻIH, TSKŻ, sygn. 325/148, [b.p.], Do ambasadora ZSRR tow. Sobolewa, 8 III 1953 r.

22 ŻIH, TSKŻ, sygn. 325/143, [b.p.], S. Petrycer, Sprawozdanie z delegacji w Bielsku Podlaskim w dniu 8-ego i 9-ego maja 1954 r.; Opisowe sprawozdanie z przebiegu przerejestracji członków i werbunku nowych członków TSKŻ w Białymstoku, 27 marca 1954 r. 
Podobna była liczba prenumeratorów żydowskich gazet ${ }^{23}$. Stopniowo zmniejszano liczbę pracowników etatowych oddziału - początkowo było to 6 osób (po trzech umysłowych i fizycznych), ale w 1953 r., gdy okazało się, że nie zebrano nawet ankiet od członków, Zarząd Główny zlikwidował ostatni etat sekretarza, pozostawiając 1/2 etatu sekretarza technicznego. Został nim Sender Petrycer, który równolegle pracował jako kioskarz „Ruchu”24.

Działalność TSKŻ polegała na ograniczonej pomocy socjalnej, świadczonej często w formie doraźnej, najczęściej jednorazowych zapomóg, ale też stałych rent czy lekarstw oraz skromnej działalności kulturalnej. Towarzystwo rozprowadzało wydawnictwa warszawskiej centrali (własnych nie miało), a także obowiązkowo - prasę radziecką i książki typu: Przemówienie na V sesji Rady Najwyższej ZSRR Malenkowa czy 50 lat KPZR, w czym zresztą - co nie dziwne - nie było zbyt skuteczne. Organizowało też wieczory autorskie, prowadziło klub z biblioteką, wyposażoną m.in. w radio, telewizor i adapter ${ }^{25}$. Zarząd oddziału białostockiego czuł się zaniedbywany przez Warszawę, wskazując na bezskuteczne przez siedem lat starania o przyjazd Teatru Żydowskiego z Warszawy, czy gorsze traktowanie przez Centralną Żydowską Komisję Pomocy Społecznej ${ }^{26}$. Na marginesie warto zauważyć, iż mała aktywność społeczna i poczucie upośledzenia względem reszty kraju dotyczyło większości mieszkańców Białegostoku, bez względu na narodowość.

Tutejsza społeczność żydowska, a zwłaszcza TSKŻ, mobilizowały się jednak przy organizacji obchodów kolejnych rocznic powstania $w$ getcie białostockim z sierpnia 1943 r., co było tradycją zapoczątkowaną już w 1945 r. Zapewne miało na to wpływ pierwszoplanowe znaczenie pamięci dla społeczności żydowskiej, a ułatwieniem było zaangażowanie innych instytucji i organizacji społecznych, a zwłaszcza organów władz, których przedstawiciele uczestniczyli w większości uroczystości. W 1950 r. 14 uczestników walk w getcie (z tego tylko dwóch żyjących) zostało odznaczonych przez ministra obrony narodowej krzyżami partyzanckimi ${ }^{27}$. W 1953 r. 10. rocznicę powstania uczczono złoże-

\footnotetext{
$23 \mathrm{~W}$ pierwszej połowie lat pięćdziesiątych w Białymstoku było 40 prenumeratorów wydawnictw „Jidysz Buch” i 45 - „Fołks Sztyme”, ŻIH, TSKŻ, sygn. 325/154, [b.p.], Lista abonentów Fołks Sztyme (Głos Ludu) na I kwartał 1954 r.

${ }^{24}$ ŻIH, TSKŻ, sygn. 325/146, [b.p.], Pismo TSKŻ do Prezydium WRN w Białymstoku, 6 II 1951 r.; sygn. 325/148, [b.p.], Pismo TSKŻ w Polsce do TSKŻ w Białymstoku, 23 VII 1953 r.; sygn. 325/149, [b.p.], Prezydium TSKŻ w Warszawie, 26 XI 1954 r.

${ }_{25}$ ŻIH, TSKŻ, sygn. 325/148, [b.p.], Wykaz kolportowanych książek i broszur abonentom „Jidisz Buch" od 15 X 1953 r.; A. Pyżewska, op. cit., s. 87.

26 ŻIH, TSKŻ, sygn. 325/142, [b.p.], Protokół z ogólnego zebrania członków TSKŻ w Polsce Oddz. w Białymstoku odbytego 23 marca 1958 r. w Klubie Towarzystwa przy ul. Pięknej w Białymstoku.

27 ŻIH, Wojewódzki Komitet Żydowski w Białymstoku, sygn. 362/17, [b.p.], Do Związku Bojowników o Wolność i Demokrację Zarząd Okręgu w Białymstoku, 17.08.1950.
} 
niem kwiatów na cmentarzu, zaciągnięciem warty honorowej pod pomnikiem powstańców, akademią w Teatrze im. Węgierki z udziałem orkiestry wojskowej (grała hymn państwowy i „Międzynarodówkę”) oraz spektaklami Państwowego Teatru Żydowskiego. Oczywiście program był konsultowany z KW PZPR, teksty zatwierdzone przez cenzurę. Jak wiemy z lokalnej prasy, w 1954 r. w sierpniowej akademii z okazji rocznicy powstania uczestniczyło ponad 200 osób, w tym przedstawiciele organizacji społecznych i zakładów pracy. W trakcie uroczystości odsłonięto tablicę pamiątkową poświęconą Malmedowi, umieszczoną na ścianie nowego budynku ${ }^{28}$.

W omawianym okresie organizacja żydowska nie miała już możliwości sprawowania bezpośredniej opieki nad miejscami pamięci i cmentarzami, którą sprawowała w okresie tużpowojennym. W 1951 r. TSKŻ zwróciło się do Wojewódzkiej Rady Narodowej o uporządkowanie miejsc straceń w Grabówce i Pietraszach oraz cmentarza na terenie dawnego getta ${ }^{29}$. O ile dwa pierwsze miejsca zostały upamiętnione i zachowane (Pomnik Ofiar Wojny w Grabówce stanął dopiero w 1973 r.), o tyle już w 1953 r., w związku z budową osiedla mieszkaniowego, pojawiło się niebezpieczeństwo zniszczenia cmentarza przy ul. Żabiej, miejsca spoczynku 9 tysięcy osób. W liście protestacyjnym do KW PZPR białostocki Zarząd TSKŻ pisał: „Cmentarz ten stanowi reliquium narodowe, poza tym nie jest to cmentarz w zwykłym znaczeniu tego słowa, lecz miejsce kaźni tysięcy obywateli polskich, a jak wiadomo Polska ludowa dotychczas nie przeniosła ani jednego miejsca kaźni z okupacji hitlerowskiej; wręcz przeciwnie - każdy, bodaj najskromniejszy skrawek ziemi, na którym odbywały się egzekucje lub padli patrioci w walce z okupantem jest otoczony czcią" ${ }^{30}$. W UdSW interweniował w tej sprawie Żydowski Instytut Historyczny, przestrzegając przed profanacją pamięci i niszczeniem dzieł sztuki oraz ostrzegając przed efektem propagandowym takiej decyzji. Dzięki staraniom środowiska została ona wówczas wstrzymana ${ }^{31}$.

W latach pięćdziesiątych ostatecznie przestał istnieć cmentarz przy ul. Sosnowej, użytkowany od 1900 r., zniszczony w czasie wojny i zasypany gruzami. Teren został zajęty na mocy dekretu z 26 kwietnia 1949 r. o nabywaniu i przekazywaniu nieruchomości niezbędnych do realizacji narodowych planów gospodarczych - na potrzebę budowy bloków osiedla robotniczego ${ }^{32}$. W $1963 \mathrm{r}$. Ministerstwo Gospodarki Komunalnej sporządziło spis nieczynnych cmentarzy

28 ŻIH, TSKŻ, sygn. 325/147, [b.p.], Pismo TSKŻ do KW PZPR w Białymstoku, 28 VII 1953 r.; sygn. 325/149, [b.p.] Sprawozdanie, 19 VIII $1957 \mathrm{r}$.

${ }^{29}$ ŻIH, TSKŻ, sygn. 325/146, [b.p.], Pismo do WRN w Białymstoku, VI $1951 \mathrm{r}$.

30 ŻIH, TSKŻ, sygn. 325/148, [b.p.], Pismo do KW PZPR w Białymstoku, 14 grudnia 1953 r.

31 ŻIH, TSKŻ, sygn. 325/149, [b.p.], Komenda Miasta Milicji Obywatelskiej w Białymstoku, 4 V $1954 \mathrm{r}$.

32 K. Urban, op. cit., s. 451-460. 
żydowskich i zaproponowało likwidację wszystkich zlokalizowanych w Białymstoku (za wyjątkiem czynnego, przy ul. Wschodniej). W 1964 r. na wniosek Miejskiej Rady Narodowej zamknięto cmentarz przy ul. Bema zwany cholerycznym, gdyż utworzono go po epidemii w $1831 \mathrm{r}$. Na jego terenie powstała hala targowa i bazar. Całkowicie znikł też założony w XVIII w. cmentarz rabinacki przy ul. Kalinowskiego. Na terenie zniszczonej przez Niemców nekropolii w 1948 r. postanowiono utworzyć Park Centralny. Pozostałości zasypano ziemią na początku lat pięćdziesiątych, a ostatnie elementy dwadzieścia lat później, przy budowie amfiteatru. Część macew została wykorzystana np. do budowy murków na Rynku Kościuszki czy fontanny w parku ${ }^{33}$. Nie zachowały się dokumenty, które świadczyłyby o próbach obrony cmentarza.

Śmierć Stalina, a zwłaszcza przełom polityczny 1956 r., przyniosły pewną liberalizację, zarówno w ZSRR, jak i w Polsce, czego efektem była m.in. kolejna, ćwierćmilionowa fala repatriantów ze Wschodu. Wśród niej była również ludność żydowska, ale tym razem do Białegostoku trafiło tylko 16 rodzin, jednak i tak był problem ze znalezieniem im mieszkań i pracy ${ }^{34}$. W skali kraju silniejszy był jednak ruch w inną stronę - nowa władza zgodziła się na wyjazd z Polski 50 tysięcy Żydów, czyli ponad połowy mieszkających w kraju. Wśród przyczyn fali wyjazdów, zwanej ironicznie ,aliją Gomułki”, były niezrealizowane dążenia $\mathrm{z}$ lat czterdziestych i ciężkie warunki życia w Polsce, ale też obawy przed nastrojami nacjonalistycznymi i pogłębiające się uczucie wyobcowania ${ }^{35}$. W Białymstoku także pojawiła się ,„panika wyjazdowa”" ${ }^{36}$, ale brak źródeł, które pozwoliłyby określić skalę zjawiska. Wiadomo jedynie, że w 1958 r. paszporty na wyjazd stały albo dokumenty podróży otrzymało 8 osób, które udawały się do Izraela, Australii i Anglii. W 1959 r. wyjechało 15 osób $^{37}$. Choć aliję zakończono w 1960 r., z Białegostoku w pierwszej połowie lat sześćdziesiątych co roku wyjeżdżało kilka - kilkanaście osób.

Zdarzały się też powroty. Przykładem może być historia Szymona (Szyi) Bartnowskiego, ocalonego z getta białostockiego i Auschwitz, który w 1957 r. wyjechał z żoną Polką i dziećmi na pobyt stały do Izraela. Dla tej mieszanej rodziny wyjazd okazał się wielkim rozczarowaniem ze względu na chłodne

33 Archiwum Akt Nowych, Ministerstwo Gospodarki Komunalnej, sygn. 9/25, Wykaz żydowskich nieczynnych cmentarzy proponowanych do zamknięcia na terenie województwa białostockiego, 1963; D. Stankiewicz, Aneks. Żydowskie cmentarze, miejsca egzekucji i mogity wojenne, [w:] D. Boćkowski, E. Rogalewska, J. Sadowska, op. cit., s. 109-112.

34 ŻIH, TSKŻ, sygn. 325/142, [b.p.], Protokół z walnego zebrania członków TSKŻ Oddział w Białymstoku odbytego w dniu 10 grudnia 1957 r. oraz 6 lutego 1958 r.

35 D. Stola, Kraj bez wyjścia? Migracje z Polski 1949-1989, Warszawa 2010, s. 133-136.

36 Pisała o tym m.in. Regina Bartnowska - Archiwum Instytutu Pamięci Narodowej [dalej: AIPN], sygn. Bi 93/3455/18, k. 9, Akta paszportowe: Bartnowski Szymon.

37 AIPN, sygn. IPN Bi 127/32/3, Rejestr spraw ubiegających się o wyjazd do państw kapitalistycznych za rok 1958/59; ŻIH, TSKŻ, sygn. 325/149, [b.p.], Pismo do ZG TSKŻ, 22 IV 1958 r. 
przyjęcie i trudności z aklimatyzacją ${ }^{38}$. Po trwających 3 lata staraniach uzyskali zgodę polskich władz na powrót, ale ich syn w 1970 r. ponownie wyjechał do Izraela na stałe i zamieszkał w kibucu.

Dane dotyczące liczby żydowskich mieszkańców Białegostoku w latach sześćdziesiątych są niepełne i niespójne. Najwyższą liczbą jest 230 osób, które podawało TSKŻ w 1961 r., jednocześnie określając ówczesną liczbę swoich członków na 76 osób ${ }^{39}$.

Wydawało się, że popaździernikowa odwilż pozytywnie wpłynie na życie ludności żydowskiej pozostałej w kraju. Powrócił do Polski usunięty w czasach stalinowskich Joint, dzięki czemu znowu pojawiła się możliwość dystrybucji paczek z zagranicy, udzielania zapomóg. Szansą na uzyskanie swego przedstawicielstwa w lokalnych gremiach (przynajmniej formalnie) decyzyjnych była decyzja Komisji Mniejszości Narodowych przy KW PZPR w Białymstoku o dopuszczeniu TSKŻ do kampanii wyborczej do Rad Narodowych w 1958 r. W ramach Frontu Jedności Narodu Oddział wystawił swoich kandydatów: Hakmajera do MRN w Białymstoku i dr. Grochowskiego (dyrektora szpitala w Łomży) do WRN. Hersz Hakmajer faktycznie został białostockim radnym ${ }^{40}$.

Po 1956 r. na krótko zaktywizował TSKŻ sekretarz Dawid Cygielnicki, który przyjechał z ZSRR. Jednym z większych jego sukcesów było zorganizowanie w 1958 r. imprezy purymowej, w której uczestniczyło 80 dzieci z Białegostoku i Bielska Podlaskiego. Prowadzono ją w dwu językach, dzieci obdarowano paczkami $^{41}$. Tego roku Świętu Purym poświęcono nawet audycję w białostockiej rozgłośni Polskiego Radia. Generalnie, widać było też pewne zainteresowanie społeczne problematyką żydowską. W 1957 r. „Gazeta Białostocka” opublikowała cykl korespondencji z Izraela Włodzimierza Bieleńskiego 49 dni w kraju sześcioramiennej gwiazdy, opisujący m.in. sytuację emigrantów z Polski. Autor dość życzliwie obserwował „Jak naród rośnie”, podziwiał kibucników, ale podkreślał trudności, pisał o ludziach żałujących swej decyzji, o ośmiu tysiącach pragnących powrócić do Polski, o dużym autorytecie Gomułki i Cyrankiewicza ${ }^{42}$.

W 1958 r. szczególnie uczczono 15. rocznicę powstań w gettach warszawskim i białostockim, w organizację uroczystości lokalnych angażowały się lokalne władze i instytucje społeczne. Komitet Społeczny powołany przed 15. rocznicą

\footnotetext{
38 AIPN, sygn. IPN Bi 93/3455/18, k. 9, Akta paszportowe: Bartnowski Szymon.

39 A. Pyżewska, op. cit., s. 85.

40 ŻIH, TSKŻ, sygn. 325/142, [b.p.], Protokół z posiedzenia Towarzystwa Społ.-Kultural. Żydów w Polsce Oddz. w Białymstoku w dniu 29 XII 1957; „Dziennik Urzędowy Wojewódzkiej Rady Narodowej w Białymstoku" 1958, nr 1, s. 1.

41 ŻIH, TSKŻ, sygn. 325/142, [b.p.], Sprawozdanie opisowe z imprezy ku czci Święta Purym przeprowadzonej w Białymstoku z inicjatywy Oddz. TSKŻ w Białymstoku, 10 marca $1958 \mathrm{r}$.

42 W. Bieleński, 49 dni w kraju sześcioramiennej gwiazdy, „Gazeta Białostocka”, nr 189, 10-11.08.1957, s. 1, 2, 5; nr 195, 17-18.08.1957, s. 1, 4; nr 201, 24-25.08.1957, s. 5.
} 
w 1958 r. złożony był z przedstawicieli PZPR, ZSL, SD, „robotników fabrycznych, przedstawicieli Wojska Polskiego, Wojewódzkiej Rady Narodowej, Frontu Jedności Narodu, ZBoWiD itd.”. Białostockich Żydów reprezentowali w nim Hakmajer, Ostryński i Paszko ${ }^{43}$. Dzięki staraniom TSKŻ 16 sierpnia na południowej, szczytowej ścianie nowo wzniesionego budynku przy ul. Wesołowskiego 1 (obecnie Suraska), należącego do Robotniczej Spółdzielni Wydawniczej, wmurowano ufundowaną przez TSKŻ i ZBoWiD tablicę pamiątkową z napisem w językach polskim i hebrajskim: „Świetlanej pamięci trzech tysięcy męczenników żydowskich żywcem spalonych w dużej synagodze w Białymstoku przez hitlerowskich morderców w dniu 24 czerwca 1941 r." ${ }^{44}$. Pod tablicą znajdował się symboliczny grób otoczony ogrodzeniem z rur stalowych, wspartych na dwóch betonowych słupach. Wieczorem odbyła się akademia w Teatrze im. Węgierki z udziałem uczestników powstania. O uroczystościach krótko informowała „Gazeta Białostocka", która w numerze z 16-17 sierpnia zamieściła także, choć bez komentarza, wiersz Władysława Broniewskego Żydom polskim. Pamięci Szmula Zygielbojma ${ }^{45}$.

Wyjątkowym, choć drobnym wydarzeniem w mieście było wystawienie przez amatorski Teatr Poezji „Metafora” przy Wojewódzkim Domu Kultury spektaklu „Dawid i Goliat”. Scenariusz oparty był na pamiętniku Dawidka Rubinowicza i zeznaniach Adolfa Eichmanna przed sądem izraelskim i miał być formą uczczenia pamięci białostockich Żydów ${ }^{46}$.

W takim, względnie sprzyjającym działalności żydowskiej, klimacie w lutym 1958 r. w walnym zebraniu Oddziału TSKŻ uczestniczyło 70 osób, w marcu - 50 . Co ciekawe, wyrażano wtedy zadowolenie, że zapisali się do Towarzystwa już prawie wszyscy Żydzi mieszkający w Białymstoku, czemu przeczą inne statystyki. Nikt jednak nie chciał podjąć się poprowadzenia dla dzieci kursu języka jidysz ${ }^{47}$. Pracę Oddziału coraz bardziej jednak utrudniały konflikty personalne, owocujące kłótniami na zebraniach, pisaniem skarg do Zarządu Głównego (np. Cygielnickiego oskarżano nawet o sprzedawanie zawartości przesyłanych do Oddziału paczek). W związku z taką sytuacją wybory przewodniczącego w lutym 1958 r. odbywały się w obecności przedstawiciela ZG, ale doprowadziły do ogłoszenia przez niego rozwiązania Oddziału. Oprotestowano to jako próbę

43 Przed 15 rocznica powstania w getcie białostockim, „Nasz Głos. Dodatek do Fołks-Sztyme”, 19.07.1958, nr 14, s. 3.

44 Data jest błędna - w rzeczywistości miało to miejsce 27 czerwca.

45 W. Broniewski, Żydom polskim. Pamięci Szmula Zygielbojma, „Gazeta Białostocka”, nr 195, 16-17.08.1958, s. 3; 15 rocznica powstania w getcie białostockim, „Gazeta Białostocka”, nr 196, 18.08.1958, s. $1,3$.

46 H. Hakmajer, „Dawid $i$ Goliat” w Białymstoku, „Nasz Głos. Dodatek do Fołks-Sztyme”, nr 6, 24.03.1962, s. 3.

47 A. Pyżewska, op. cit., s. 93. 
„przywożenia w teczce sekretarzy i przewodniczących”. Sytuacja w Białymstoku skłoniła jednego z działaczy, Kasiela Lustmana, do wezwania: „Nadszedł czas, żeby w naszej małej rodzinie zapanował pokój i przyjaźń, i żeby człowiek nie był człowiekowi wilkiem. Jesteśmy dość bici tym, że jesteśmy Żydami. Jak mogą nas uważać Polacy, skoro w naszej rodzinie nie ma pokoju i jedności”, a przedstawiciela Zarządu Głównego, Henryka Cieszyńskiego, do gorzkiej refleksji: „Hitlerowcy wymordowali kwiat naszego narodu, jesteśmy zmuszeni pracować z tymi, którzy pozostali przy życiu"48. Oddział przetrwał, ale w następnym okresie nie miał zewidencjonowanych członków, nie dysponował złożonymi deklaracjami, nie zbierano składek, wstrzymano mu subwencje. ZG zrezygnował z przeprowadzenia wyborów białostockiego zarządu, mianując w 1960 r. przewodniczącym Hersza Hakmajera. Temu udało się pozyskać 88 deklaracji, ale nie oznaczało to zmiany jakościowej pracy Oddziału ${ }^{49}$. Trzy lata później znowu informowano lokalne władze o rozpadzie zarządu i braku zainteresowania działalnością ze strony społeczeństwa żydowskiego ${ }^{50}$. Przed decyzją o formalnej likwidacji struktury w mieście powstrzymywała władze partyjne jedynie obawa przed jej negatywnym odbiorem. Białostocki Oddział TSKŻ istniał jeszcze do 1970 r. W 1967 r. na papierze miał 36 członków, ale na żydowski Nowy Rok nie udało się zebrać tzw. minianu, czyli 10 mężczyzn - dorosłych, pobożnych Żydów, spełniających warunki uczestnictwa w spotkaniu modlitewnym (posiadających odpowiednią wiedzę religijną i minimalną znajomość języka hebrajskiego) ${ }^{51}$.

O zamierającej aktywności białostockiego środowiska świadczy coraz rzadsze pojawianie się informacji z miasta na łamach „Fołks-Sztyme”, jedynej wówczas ukazującej się w Polsce żydowskiej gazety, organu TSKŻ. Pisząc o działaniach organizacji często przywoływano Warszawę, Kraków, Łódź, ale też na przykład Żory, Dzierżoniów, Legnicę czy Szczecin, Białegostoku prawie nigdy. Nazwa miasta pojawiała się na łamach gazety co roku w sierpniu, gdy przypominano wydarzenia powstania w tutejszym getcie. Zawsze wtedy poświęcano jego historii kilka stron, przywołując odezwy i wspomnienia, publikując nieliczne zdjęcia, plany, portrety przywódców - Mordechaja Tenenbauma (Tamarowa) i Daniela Moszkowicza, inspirowane wydarzeniami obrazy... Posiłkowano się tu często opracowaniami Szymona Datnera, w 1968 r. jego tekst Szkice

48 ŻIH, TSKŻ, sygn. 325/142, [b.p.], Protokół z walnego zebrania członków TSKŻ Oddział w Białymstoku odbytego w dniu 10 grudnia 1957 r. oraz 6 lutego 1958 r.; Protokół z ogólnego zebrania członków TSKŻ w Polsce Oddz. w Białymstoku odbytego 23 marca 1958 r. w Klubie Towarzystwa przy ul. Pięknej w Białymstoku.

49 ŻIH, TSKŻ, sygn. 325/149, [b.p.], Pismo do ZG TSKŻ w Warszawie, 10 V 1960 r.

50 Archiwum Państwowe w Białymstoku [dalej: APB], Komitet Wojewódzki PZPR w Białymstoku [dalej: KW PZPR], sygn. 2146, k. 231, Protokół posiedzenia Prezydium Komisji Narodowościowej przy KW PZPR w Białymstoku, 10 X 1963.

51 A. Pyżewska, op. cit., s. 93. 
do studiów nad dziejami żydowskiego ruchu partyzanckiego w Okręu Biatostockim (1941-1944) drukowano w częściach w kolejnych sześciu numerach. Więcej uwagi poświęcano na tych łamach jedynie powstaniu w getcie warszawskim.

Rocznicowe obchody w latach sześćdziesiątych stały się najważniejszym przedsięwzięciem środowiska białostockich Żydów, przy czym do ich organizacji potrzebowało ono już wsparcia z zewnątrz. Szczególny charakter miały w 20. rocznicę, która przypadła w 1963 r. Teraz na czele komitetu honorowego stanął osobiście I sekretarz Komitetu Wojewódzkiego PZPR, a w jego skład wchodzili inni miejscowi notable (np. przewodniczący okręgowej rady Związków Zawodowych i dyrektor fabryki pluszu), a także przedstawiciele ZG TSKŻ. Dzięki wsparciu instytucji państwowych było to wyjątkowo duże przedsięwzięcie - uczestniczyła w nim kompania honorowa wojska, orkiestra kolejarska, poczty sztandarowe oraz tłum ludzi, w tym rodziny więźniów getta przybyłe z całego kraju. Przemaszerowano z ul. Wesołowskiego, miejsca spalonej Wielkiej Synagogi, koło tablicy poświęconej Malmedowi, pod którą złożono wieńce, na cmentarz w dawnym getcie, gdzie odbył się apel poległych. Uroczystości zamknęła wieczorna akademia $\mathrm{z}$ referatem dyrektora ŻIH, prof. Bernarda Ber Marka, i spektaklem w wykonaniu aktorów Teatru Żydowskiego. Wydarzenia sprzed dwudziestu lat przypominała białostoczanom lokalna prasa, a w zakładach pracy organizowano okolicznościowe pogadanki na temat „znaczenia powstania w getcie białostockim jako wkładu do ogólnej walki z hitleryzmem o wolność Polski”s2.

Co ciekawe, mocno zaakcentowane, choć skromniejsze niż pięć lat wcześniej, były obchody 25. rocznicy powstania w pamiętnym 1968 r., zorganizowane pod patronatem Frontu Jedności Narodu, przy udziale „Gazety Białostockiej”, ZBoWiD i oczywiście Oddziału TSKŻ. Złożono kwiaty pod dwiema tablicami - pamięci Izaaka Malmeda i upamiętniającej spalenie Wielkiej Synagogi, a w siedzibie Związków Zawodowych odbyła się wieczornica ${ }^{53}$. Nieznane są teksty wygłoszonych wówczas przemówień, ale można domyślać się, że korespondowały one z artykułem opublikowanym w „Gazecie Białostockiej”. Przypomniano w nim wydarzenia z 1943 r., dodając komentarz w duchu propagandy charakterystycznej dla okresu po wojnie sześciodniowej i akcji antysemickiej w Polsce: „Zniekształcając i fałszując fakty historyczne rząd Izraela przerzuca odpowiedzialność za tragedię narodu żydowskiego na naród polski. W ślepej nienawiści do narodu polskiego przywódcy Izraela i międzynarodowego syjonizmu nie chcą pamiętać tej prawdy historycznej, że to od Polaków, a nie od Niemców

52 (T.), W XX rocznice powstania w białostockim getcie, „Nasz Głos. Dodatek do Fołks-Sztyme”, nr 16, 24.08.1963, s. 2; Obchody rocznicy powstania w białostockim getcie, „Gazeta Białostocka”, nr 194, 17-18.08.1963, s. 1-2.

53 W Białymstoku - w 25-lecie powstania w getcie, ,Nasz Głos. Dodatek do Fołks-Sztyme”, nr 33, 17.08.1968, s. 1 . 
Żydzi otrzymywali żywność, lekarstwa, broń i amunicję. To żołnierze polskiego podziemia ginęli w walce spiesząc z pomocą ludności żydowskiej”" ${ }^{4}$. Trzeba tu przypomnieć, że $\mathrm{w}$ przypadku powstania $\mathrm{w}$ getcie białostockim pomoc polska była znikoma.

Przytoczone powyżej słowa wpisują się oczywiście w klimat Marca '68 i akcji antyizraelskiej i antysemickiej, która rozpoczęła się już w 1967 r., po zwycięstwie Izraela w wojnie sześciodniowej, pozytywnie odebranym przez część polskiego społeczeństwa. W Białymstoku początkowo polegała ona na wzmożeniu inwigilacji środowiska żydowskiego przez Służbę Bezpieczeństwa. Poddano jej zarówno osoby aktywne w TSKŻ, jak i tylko mające żydowskie pochodzenie. Szczególnie przyglądano się prof. Jakubowi Chlebowskiemu (Jakub Frydman, kierownik II Kliniki Chorób Wewnętrznych Akademii Medycznej w Białymstoku, w latach 1959-1962 rektor tej uczelni), który, choć wcześniej w dokumentach podawał narodowość polską, teraz miał mówić, iż czuje dumę, iż jest Żydem $^{55}$. Na sporządzonej liście mieszkańców województwa popierających Izrael znalazło się 60 osób, zarówno Żydów, jak i Polaków, w tym 25 białostoczan ${ }^{56}$. 8 czerwca $1967 \mathrm{r}$. wpłynęła pierwsza umotywowana politycznie prośba o uznanie narodowości żydowskiej i zgodę na wyjazd do Izraela w celu walki z Arabami - złożył ją student Wyższej Szkoły Inżynierskiej w Białymstoku, Witold Szer. Miał też zrzec się ,,przynależności do narodowości polskiej, pod jaką dotychczas występował". Prawdopodobnie odmówiono $\mathrm{mu}^{57}$.

Marzec 1968 r. był okresem bardzo trudnym dla żydowskiej organizacji popierającej system, jaką było TSKŻ. SB stwierdzało, że „W środowisku tym obserwuje się konsternację i obawy, aby wystąpienia studentów nie przybrały charakteru pogromu Żydów zamieszkałych w Polsce"s8. W oficjalnym oświadczeniu białostockiego Zarządu Oddziału TSKŻ odcinano się od syjonizmu, deklarując, iż „Żydzi w Polsce mają tylko jedną ojczyznę, jest nią Polska Rzeczypospolita Ludowa. (...) Tylko w krajach socjalistycznych, Żydzi są równouprawnionymi obywatelami. Tylko dzięki zwycięstwu Armii Radzieckiej nad hitlerowskimi Niemcami, część Żydów została uratowana od zagłady. (...) Uczynimy

54 (CH), 25 rocznica powstania w getcie, ,„Gazeta Białostocka”, nr 194, 16.08.1968, s. 6.

55 APB, KW PZPR, sygn. 1415, k. 36, Informacja dot. sytuacji operacyjno-politycznej i nastrojów wśród społeczeństwa, 23.11.1967; k. 43-44, Informacja, 7.02.1968.

56 AIPN, sygn. IPN Bi 045/2161, k. 71-72, Wykaz osób wrogo występujących i popierających agresję Izraela na kraje arabskie zarejestrowanych w ewidencji aktów wrogiej działalności przez jednostki operacyjne w 1967 roku, 22.03.1968.

57 AIPN, sygn. IPN Bi 045/1680, k. 94, Meldunek dot. sytuacji w województwie w związku z konfliktem na Bliskim Wschodzie z dn. 8.06.67. W zestawieniach za 1967 r. pojawia się tylko jeden wniosek dotyczący wyjazdu do Izraela załatwiony odmownie. Prawdopodobnie dotyczy właśnie tej osoby - AIPN, sygn. IPN Bi 127/8/2, k. 50, Zestawienie z wyjazdów czasowych i emigracyjnych do „KK” woj. białostockiego za $1967 \mathrm{r}$.

58 AIPN, sygn. Bi 045/2, k. 57, Meldunek, 17.03.1968 r. 
wszystko, co będzie w naszej skromnej mocy - dla rozkwitu naszej ojczyzny Polski Ludowej”. Nie ma tu najmniejszej próby wstawienia się za ludźmi, którzy stali się celem nagonki, ale nie taki był sens tego dokumentu ${ }^{59}$. Postawa Oddziału białostockiego nie była wyjątkowa, w podobnym duchu wypowiadały się też inne, a także żydowska prasa ${ }^{60}$.

Choć na białostockich dwóch uczelniach wiosną 1968 r. w porównaniu $\mathrm{z}$ resztą kraju prawie nic się nie działo, obowiązujący schemat działania nakazywał „demaskować” jako syjonistów ich pracowników. Jak poinformowano, „Pod wpływem krytyki dotychczasowej jego działalności w Akademii Medycznej złożył rezygnację z zajmowanego środowiska" prof. Janusz Lesiński, kierownik Kliniki Dermatologii (w 1957 r. odwołany z egzekutywy KW PZPR za „zaniedbywanie partyjnych obowiązków" ${ }^{61}$. Najbardziej poruszająca była sprawa prof. Jakuba Chlebowskiego, na wniosek Komitetu Uczelnianego PZPR zdjętego ze stanowiska kierownika kliniki „z powodu wrogiej postawy, jaką zajął w okresie agresji izraelskiej i braku odpowiednich kwalifikacji do sprawowania funkcji dydaktyczno-wychowawczej". Profesor Chlebowski został też odwołany z pełnionych funkcji społecznych m.in. w FJN i TPPR ${ }^{62}$. Na skutek wzmagającej się presji wyjechał z rodziną do Izraela, co było osobistym dramatem, a wkrótce tragicznie zginął.

W 1968 r. usunięto z PZPR dawną naczelnik wydziału Wojewódzkiego Urzędu Bezpieczeństwa Publicznego, Sonię Rogowską. Zarzucono jej, iż popierała agresję Izraela i „wrogo wypowiadała się pod adresem naszego Rządu i Rządu ZSRR”, mówiła o dyskryminacji Żydów w Polsce, broniła usuwanych z partii, a także pozwoliła, by jej córka nosiła znaczek z gwiazdą Dawida. W 1981 r. Sonia Rogowska wyjechała do Izraela ${ }^{63}$.

W gęstniejącej atmosferze coraz więcej osób składało wnioski emigracyjne, wśród nich byli ludzie, którym żydowską identyfikację narzucono. Do końca 1968 r. wydano w Białymstoku 10 zezwoleń na wyjazd do Izraela. W następnym roku zgody otrzymało 58, w 1970 r. -25 osób $^{64}$. W 1969 r. sporządzono

59 APB, KW PZPR, sygn. 1368, k. 256-257, Rezolucja TSKŻ w Białymstoku, 18.03.1968; k. 258-259, Protokół nr 6/68, 18.03.1968.

60 Stowo Partii, „Nasz Głos. Dodatek do Fołks-Sztyme”, nr 13, 30.03.1968, s. 1.

61 AIPN, sygn. Bi 045/2, k. 289, Informacja nr 48, 27.04.1968 r.; APB, KW PZPR, sygn. 1415, k. 52-54, pismo J. Lesińskiego do KW PZPR, 25.04.1968.

62 AIPN, sygn. IPN Bi 045/2, k. 286, Informacja nr 46, 25.04.1968 r.; APB, KW PZPR, sygn. 1415, k. 45, Do KW PZPR w Białymstoku, 14.05.1968; sygn. 1368, k. 73, Ocena sytuacji politycznej w wyższych uczelniach woj. białostockiego w okresie ostatnich wydarzeń, 8.04.1968.

63 APB, KW PZPR, sygn. 202, k. 166-169, Treść sprawy odwoławczej Soni Rogowskiej (XI 1968); AIPN, sygn. IPN BI 98/1776, Rogowska Sonia c. Mojżesza.

${ }^{64}$ AIPN, sygn. IPN Bi 127/8/2, k. 32, 36, 40, 44, 46, 54-76, 80, 82, 84-93, Wykaz nadesłanych spraw z jednostek paszportowych na wyjazd do KDL i KK, Wykaz nadesłanych spraw z jednostek paszportowych na wyjazd do KDL i KK (od 1 maja 1968 r. do 30 listopada 1970 r.). 
wyjątkową tabelę: „Zestawienie liczbowe osób mniejszości narodowościowych ubiegających się o wyjazdy emigracyjne rok 1969". Wykazano, iż o wyjazd skutecznie ubiegało się w tym roku 35 Żydów. W grupie tej było 3 członków PZPR i 32 bezpartyjnych, 17 przedstawicieli inteligencji i 18 robotników, 5 osób z wykształceniem wyższym, 11 ze średnim i 19 z podstawowym. Otwarte były jeszcze sprawy 11 Żydów ${ }^{65}$. Niezgodności przedstawionych powyżej danych prawdopodobnie wynikają z faktu, iż razem z przedstawicielami mniejszości wyjeżdżali też członkowie rodzin będący Polakami. Wiadomo także, że znaczna część emigracji pomarcowej nie trafiła do Izraela, tylko do Szwecji, Danii, Francji i innych państw Europy Zachodniej, a także Australii, USA. Wydaje się, że z ówczesnej fali emigracji najściślejsze kontakty z Polską i Białymstokiem zachowali emigrujący do najbliższej Szwecji, jak np. Marek Trokenheim, redaktor sztokholmskich „Wiadomości Polskich” i wiceprezes Kongresu Polaków w Szwecji.

$\mathrm{Na}$ trwającej do początków lat siedemdziesiątych fali emigracji z Białegostoku wyjechało w sumie do 100 osób pochodzenia żydowskiego i ich rodzin. To niewielki ułamek około 13-tysięcznej rzeszy ludzi, którzy wówczas opuścili Polskę, ale ogromny ubytek dla lokalnej społeczności, stanowiący blisko jej połowę. Społeczność ta de facto przestała istnieć, pozostały jednostki, które liczyła już tylko SB - według jej orientacji na początku lat osiemdziesiątych na terenie całego województwa białostockiego mieszkało już tylko około 60 osób narodowości żydowskiej, w zdecydowanej większości w starszym wieku. W 1970 r. uległ likwidacji białostocki Oddział TSKŻ, którego przewodniczący Jankiel Ostryński wyjechał do Danii. O końcu ,żydowskiego świata” mówiono wówczas w odniesieniu do całej Polski, a w Białymstoku widać to było z całą ostrością

Wzmożona unifikacja życia społecznego w Polsce, która miała miejsce w latach siedemdziesiątych, przyniosła ograniczanie aktywności mniejszości narodowych, a w przypadku Żydów - zacieranie śladów ich dawnej obecności. Opuszczony przez TSKŻ budynek synagogi przy ul. Pięknej zaczął niszczeć. Przeprowadzono więc remont, w trakcie którego stracił charakterystyczne cechy architektoniczne. Podobny był los budynku synagogi Cytronów przy ul. Waryńskiego przy renowacji został zniszczony drewniany, kasetonowy strop z polichromiami, a także pozostałe zdobienia ${ }^{67}$.

$\mathrm{Na}$ początku $1971 \mathrm{r}$. przestał istnieć obroniony w latach pięćdziesiątych cmentarz „gettowy” przy ul. Żabiej. Stało się tak, choć we wrześniu 1970 r.

65 AIPN, sygn. IPN Bi 127/8/2, k. 78, Zestawienie liczbowe osób mniejszości narodowościowych ubiegających się o wyjazdy emigracyjne rok 1969.

66 A. Pyżewska, op. cit., s. 85; D. Stola, op. cit., s. 222, 230; AIPN, sygn. IPN Bi 127/31/2, Rejestr wydanych paszportów; sygn. IPN Bi 011/100, k. 59, Plan wykonawczy w sprawie obiektowej nr 11714/72 krypt. „Jafo” na 1982 r.

67 http://www.sztetl.org.pl/pl/article/bialystok/11,synagogi-domy-modlitwy-i-inne/381,boznica-cy tronow-ul-warynskiego-24a-/, dostęp: 10.03.2013. 
Przewodniczący Rady Ochrony Pomników Walki i Męczeństwa, minister Janusz Wieczorek, obiecał przedstawicielom ZG TSKŻ, proszącym o uporządkowanie zabytkowego cmentarza i jak najgodniejsze uwiecznienie pamięci bojowników i męczenników białostockiego getta, że wszystkie poczynania będą konsultowane z Zarządem Głównym Towarzystwa ${ }^{68}$. Tymczasem decyzja o likwidacji cmentarza została podjęta przez centralne władze partyjne i nie wstrzymały jej protesty Szymona Datnera i ZG TSKŻ, któremu jedynie obiecano odszkodowanie w kwocie około 190 tysięcy. W celu pozyskania gruntu pod budynki mieszkalne ekshumowano szczątki około 3,5 tysiąca ludzi, usunięto wszystkie macewy, rozebrano trzy pomniki i mauzoleum. Utworzono na miejscu niewielki skwer z mogiłą zbiorową oznaczoną tablicą ${ }^{69}$. W mieście sprawa likwidacji cmentarza nie odbiła się szerszym echem, a część prac przeprowadzano w formie czynów społecznych. Nie mógł o problemie napisać „Fołks-Sztyme”, jego echa można się dopatrzeć w kolejnych tekstach poświęconych sierpniowej rocznicy. W $1971 \mathrm{r}$. pisano wyłącznie o historii, a artykuł zilustrowany został nieaktualnym zdjęciem cmentarza z podpisem: „Obelisk na cmentarzu gettowym w Białymstoku. W tym miejscu za dwa lata wzniesiony zostanie nowy pomnik uwieczniający męczeństwo i bohaterstwo białostockiego getta"70. W następnych latach nie umieszczano już żadnych zdjęć, pisząc o złożeniu wieńców „na ulicy Żabiej, na terenie byłego cmentarza gettowego, gdzie znajduje się tymczasowy pomnik upamiętniający zmagania Żydów białostockich z hitlerowskimi oprawcami" ${ }^{1}$. Z roku na rok obchody były coraz skromniejsze, społeczność żydowską reprezentowali przedstawiciele ZG TSKŻ z Warszawy. Coraz słabsza była też znajomość wśród mieszkańców miasta jego przeszłości, w tym tradycji żydowskich. Był to m.in. efekt napływu do rozwijającego się Białegostoku ludności wiejskiej, tworzącej jego nowy krajobraz.

Przełom w zainteresowaniu historią i kulturą Żydów polskich nastąpił w latach osiemdziesiątych dzięki zmianom mentalnym, jakie zaszły w społeczeństwie w okresie „Solidarności” i ograniczeniu cenzury. Dla białostockich Żydów było jednak za późno, odchodzili już najstarsi ${ }^{72}$. Skromne działania inicjowali Polacy. W 1983 r. znowu uroczyście obchodzono rocznicę, już 40., powstania w getcie.

\footnotetext{
68 Delegacja Zarzqdu Głównego TSKŻ u Ministra J. Wieczorka, „Fołks-Sztyme”, nr 38, 19.09.1970, s. 1.

69 D. Stankiewicz, op. cit., s. 114. Na tablicy umieszczono napis: „W tym miejscu złożone są prochy około 3500 Żydów pomordowanych przez hitlerowców w akcjach eksterminacyjnych oraz poległych podczas powstania w getcie białostockim w sierpniu 1943 r.”.

70 (BH), W XXVIII rocznice powstania w getcie białostockim, „Fołks-Sztyme”, nr 33, 14.08.1971, s. 1.

71 A. Rok, Dni walki, „Fołks-Sztyme”, nr 34, 25.08.1973, s. 1.

72 Szymon Bartnowski - człowiek, który mówił o sobie, iż jest ostatnim Żydem w Białymstoku, zmarł w $2000 \mathrm{r}$.
} 
Rolę organizatora odegrał wiceprezydent miasta, Wacław Ostaszewski, określany jako „propagator kontynuowania tradycji żydowskich w Białymstoku”. Na uroczystości na placu Bohaterów Getta przyszli mieszkańcy miasta, przedstawiciele lokalnych władz, harcerze zaciągnęli wartę honorową pod tablicą pamiątkową w miejscu cmentarza gettowego. Przyjechali przedstawiciele TSKŻ z przewodniczącym ZG, Adamem Kwaterko, Związku Religijnego Wyznania Mojżeszowego z Mozesem Finkielsteinem, Państwowego Teatru Żydowskiego oraz redakcji „Fołks-Sztyme”, a przede wszystkim uczestnicy walk: Szymon Datner, Regina Wojskowska, Maryla Różycka, Marek Buch. Były przemowy, przejście do innych miejsc upamiętniających męczeństwa Żydów i zorganizowana przez Patriotyczny Ruch Odrodzenia Narodowego wieczornica w Filharmonii Białostockiej. Wielką atrakcją był recital „Tak jak u Chagalla” w wykonaniu Sławy Przybylskiej i Witolda Krzyżanowskiego. Co ważne, obchody relacjonowała lokalna prasa, przypominając białostoczanom, dla większości wówczas nieznane, wydarzenia sprzed czterdziestu lat ${ }^{73}$. Zwyczaj corocznego upamiętniania powstania w getcie powrócił do Białegostoku na stałe.

W latach osiemdziesiątych rozpoczęto porządkowanie czynnego, ale zrujnowanego cmentarza przy ul. Wschodniej, który w 1987 r. wpisano do rejestru zabytków. Wkrótce znalazła się w nim także synagoga Piaskower. W 50. rocznicę powstania $w$ getcie uporządkowano teren dawnego cmentarza gettowego, a w 2003 r. przywrócono odnaleziony oryginalny obelisk, który stał na nim do 1971 r. Wznowiono badania historyczne, lokalna popołudniówka „Kurier Podlaski" publikowała teksty dziennikarza Tomasza Wiśniewskiego i historyka Adama Czesława Dobrońskiego, dotyczące tradycji żydowskich miasta i losów jego mieszkańców. Po 1989 r. podjęto szereg prac mających na celu upamiętnienie tej części białostockiej historii, ale jej znaków trzeba w przestrzeni miasta szukać.

Powojenna historia białostockich Żydów nie jest nietypowa. We wszystkich ośrodkach powojennej Polski ludności tej ubywało na skutek emigracji i asymilacji, wszędzie kurczyła się działalność żydowskich instytucji. W omówionym tu okresie nie było żadnych szans na zatrzymanie tego procesu. Przypadek Białegostoku o tyle jest spektakularny, że proces ten przebiegał szybko i dobiegł do zupełnego końca, że chodzi o miasto będące kiedyś jednym z najważniejszych ośrodków życia żydowskiego w Polsce, a jego śladów pozostało tu wyjątkowo mało. Przyczyniły się do tego szczególnie i zniszczenia wojenne, i mocno odczuwany w czasach PRL prowincjonalny charakter stolicy Podlasia.

73 R. Saks, 40 rocznica Powstania w Getcie Białostockim, „Fołks-Sztyme”, nr 34, 3.09.1983, s. 1-3; W. Monkiewicz, Gloria victis!, „Gazeta Współczesna”, $\mathrm{nr}$ 188, 16.08.1983, s. 1, 3; W 40 rocznice powstania $w$ getcie białostockim, „Gazeta Współczesna”, nr 189, 17.08.1983, s. 1. 


\section{Jewish community in Białystok at the decline of its existence}

\section{Summary}

Białystok, which before 1939 was known as an important centre of Jewish life in Poland, in the years to follow - because of the war - stopped to be a Jewish hub. The majority of those citizens of Białystok who had survived the Holocaust, decided to abandon the ruined city which evoked bad memories. They were leaving the city gradually and, due to this process and the decisions of the communist authorities, the activities of Jewish institutions were languishing. After 1950 in the city there were fewer than 200 people who identified themselves as Jews and some of them still intended to leave the country. A department of the government-controlled Social-Cultural Association of Jews in Poland and (until 1954) a denominational congregation constituted the only still functioning Jewish institutions. The most important goal of the Jewish community was to organise celebrations commemorating subsequent anniversaries of the ghetto uprising in Białystok (1943). Limited cultural and self-helping activities were also conducted. The local Jewish community ceased to exist after 1968, when a considerable number of Polish Jews was forced to emigrate. Those who remained were mainly elderly people, who did not conduct any social activities. In the 1970s almost all of the still existing traces of Jewish presence in the city were obliterated. When, in the next decade, a wave of renewed interest in the Jewish culture came, not very numerous Poles were involved in Białystok.

Key words: Jews, Białystok, Social-Cultural Association of Jews in Poland, ghetto uprising in Białystok

\section{Bibliografia}

\section{Opracowania}

Berendt G., Życie od nowa. Instytucje i organizacje żydowskie (1944-1950), [w:] Następstwa zagłady Żydów. Polska 1944-2010, red. F. Tych, M. Adamczyk-Grabowska, Lublin: Wydawnictwo UMCS, Warszawa: Żydowski Instytut Historyczny, 2011.

Boćkowski D., Rogalewska E., Sadowska J., Kres świata białostockich Żydów, Białystok: Muzeum Wojska, Galeria Sleńdzińskich, 2013.

Bronsztejn S., Z dziejów ludności żydowskiej na Dolnym Ślasku po II wojnie światowej, Wrocław: Wydawnictwo Uniwersytetu Wrocławskiego, 1993.

Dobroński A., Miasto Białystok w Izraelu, „Białostocczyzna” 1990, nr 2 (18), s. 26-29. Historia Białegostoku, A. Cz. Dobroński, Białystok: Fundacja Sąsiedzi, 2012.

Kobrin R., Żydowski Białystok i jego diaspora, przekł. A. Musiał, Sejny: Pogranicze, Białystok: Białostocki Ośrodek Kultury, 2014. 
Mironowicz E., Polityka narodowościowa PRL, Białystok: Białoruskie Towarzystwo Historyczne, 2000.

Olejnik L., Polityka narodowościowa Polski w latach 1944-1960, Łódź: Wydawnictwo Uniwersytetu Łódzkiego, 2003.

Pyżewska A., Towarzystwo Społeczno-Kulturalne Żydów w Białymstoku (1950-1970), „Biuletyn Historii Pogranicza” 2011, nr 11, s. 83-94.

Sadowska J., Społeczność żydowska w Biatymstoku w latach 1944-1950, „Kwartalnik Historii Żydów” 2015, nr 3, s. 515-531.

Stola D., Kraj bez wyjścia? Migracje z Polski 1949-1989, Warszawa: Instytut Pamięci Narodowej, 2010.

Szaynok B., Z historia i Moskwa w tle. Polska a Izrael 1944-1968, Warszawa: Instytut Pamięci Narodowej, 2007.

Urban K., Cmentarze żydowskie, synagogi i domy modlitwy w Polsce w latach 1944-1966 (wybór materiałów), Kraków: Nomos, 2006.

\section{Źródła prasowe}

(BH), W XXVIII rocznice powstania $w$ getcie białostockim, „Fołks-Sztyme”, nr 33, 14.08.1971, s. 1.

Bieleński W., 49 dni w kraju sześcioramiennej gwiazdy, „Gazeta Białostocka”, nr 189, 10-11.08.1957, s. 1, 2, 5; nr 195, 17-18.08.1957, s. 1, 4; nr 201, 24-25.08.1957, s. 5.

Broniewski W., Żydom polskim. Pamięci Szmula Zygielbojma, „Gazeta Białostocka”, nr 195, 16-17.08.1958, s. 3; 15 rocznica powstania $w$ getcie białostockim, „Gazeta Białostocka”, nr 196, 18.08.1958, s. 1, 3.

(CH), 25 rocznica powstania w getcie, „,Gazeta Białostocka”, nr 194, 16.08.1968, s. 6.

Delegacja Zarzq̨du Głównego TSKŻ u Ministra J. Wieczorka, „Fołks-Sztyme”, nr 38, 19.09.1970, s. 1.

Hakmajer H., „Dawid i Goliat” w Białymstoku, „Nasz Głos. Dodatek do Fołks-Sztyme”, nr 6, 24.03.1962, s. 3.

Monkiewicz W., Gloria victis!, „Gazeta Współczesna”, nr 188, 16.08.1983, s. 1, 3.

Obchody rocznicy powstania w białostockim getcie, „Gazeta Białostocka”, nr 194, 17-18.08.1963, s. 1-2.

Przed 15 rocznica powstania w getcie białostockim, „Nasz Głos. Dodatek do Fołks-Sztyme", nr 14, 19.07.1958, s. 3.

Rok A., Dni walki, „Fołks-Sztyme”, nr 34, 25.08.1973, s. 1.

Saks R., 40 rocznica Powstania w Getcie Białostockim, „Fołks-Sztyme”, nr 34, 3.09,1983, s. 1-3.

Słowo Partii, „Nasz Głos. Dodatek do Fołks-Sztyme”, nr 13, 30.03.1968, s. 1.

(T.), W XX rocznice powstania $w$ białostockim getcie, „Nasz Głos. Dodatek do Fołks-Sztyme”, nr 16, 24.08.1963, s. 2. 
W Białymstoku - w 25-lecie powstania w getcie, „Nasz Głos. Dodatek do Fołks-Sztyme” nr 33, 17.08.1968, s. 1.

W 40 rocznice powstania $w$ getcie białostockim, „Gazeta Współczesna”, nr 189, 17.08.1983, s. 1 .

\section{Archiwalia}

Żydowski Instytut Historyczny (dalej: ŻIH), Towarzystwo Społeczno-Kulturalne Żydów w Polsce (dalej: TSKŻ), sygn. 325/142, [b.p.], Protokół z walnego zebrania członków TSKŻ Oddział w Białymstoku odbytego w dniu 10 grudnia 1957 r. oraz 6 lutego $1958 \mathrm{r}$.

ŻIH, TSKŻ, sygn. 325/142, [b.p.], Protokół z posiedzenia Zarządu Oddziału TSKŻ w Białymstoku w dniu 24 II 1958 r.

ŻIH, TSKŻ, sygn. 325/142, [b.p.], Protokół z ogólnego zebrania członków TSKŻ w Polsce Oddz. w Białymstoku odbytego 23 marca 1958 r. w Klubie Towarzystwa przy ul. Pięknej w Białymstoku.

ŻIH, TSKŻ, sygn. 325/142, [b.p.], Protokół z posiedzenia Towarzystwa Społ.-Kultural. Żydów w Polsce Oddz. w Białymstoku w dniu 29 XII 1957.

ŻIH, TSKŻ, sygn. 325/142, [b.p.], Sprawozdanie opisowe z imprezy ku czci Święta Purym przeprowadzonej w Białymstoku z inicjatywy Oddz. TSKŻ w Białymstoku, 10 marca $1958 \mathrm{r}$.

ŻIH, TSKŻ, sygn. 325/142, [b.p.], Protokół z walnego zebrania członków TSKŻ Oddział w Białymstoku odbytego w dniu 10 grudnia 1957 r. oraz 6 lutego 1958 r.

ŻIH, TSKŻ, sygn. 325/142, [b.p.], Protokół z ogólnego zebrania członków TSKŻ w Polsce Oddz. w Białymstoku odbytego 23 marca 1958 r. w Klubie Towarzystwa przy ul. Pięknej w Białymstoku.

ŻIH, TSKŻ, sygn. 325/143, [b.p.], S. Petrycer, Sprawozdanie z delegacji w Bielsku Podlaskim w dniu 8-ego i 9-ego maja 1954 r.

ŻIH, TSKŻ, sygn. 325/143, [b.p.], Opisowe sprawozdanie z przebiegu przerejestracji członków i werbunku nowych członków TSKŻ w Białymstoku, 27 marca 1954 r.

ŻIH, TSKŻ, sygn. 325/146, [b.p.], Protokół zdawczo-odbiorczy, 15 stycznia 1951 r.

ŻIH, TSKŻ, sygn. 325/146, [b.p.], Pismo TSKŻ do Prezydium WRN w Białymstoku, 6 II $1951 \mathrm{r}$.

ŻIH, TSKŻ, sygn. 325/146, [b.p.], Pismo do WRN w Białymstoku, VI 1951 r.

ŻIH, TSKŻ, sygn. 325/146, [b.p.], Pismo TSKŻ do WRN w Białymstoku, 5 VI 1951 r.

ŻIH, TSKŻ, sygn. 325/147, [b.p.], Wykaz członków TSKŻ w Polsce na rok 1952.

ŻIH, TSKŻ, sygn. 325/147, [b.p.], Pismo TSKŻ do KW PZPR w Białymstoku, 28 VII $1953 \mathrm{r}$.

ŻIH, TSKŻ, sygn. 325/148, [b.p.], Pismo do TSKŻ, 22 VI 1953 r.

ŻIH, TSKŻ, sygn. 325/148, [b.p.], Do ambasadora ZSRR tow. Sobolewa, 8 III 1953 r.

ŻIH, TSKŻ, sygn. 325/148, [b.p.], Pismo TSKŻ w Polsce do TSKŻ w Białymstoku, 23 VII $1953 \mathrm{r}$. 
ŻIH, TSKŻ, sygn. 325/148, [b.p.], Wykaz kolportowanych książek i broszur abonentom „Jidisz Buch” od 15 X 1953 r.

ŻIH, TSKŻ, sygn. 325/148, [b.p.], Pismo do KW PZPR w Białymstoku, 14 grudnia $1953 \mathrm{r}$.

ŻIH, TSKŻ, sygn. 325/149, [b.p.], Pismo do ZG TSKŻ, 22 IV 1958 r.

ŻIH, TSKŻ, sygn. 325/149, [b.p.], Komenda Miasta Milicji Obywatelskiej w Białymstoku, $4 \mathrm{~V} 1954 \mathrm{r}$.

ŻIH, TSKŻ, sygn. 325/149, [b.p.], Pismo do ZG TSKŻ w Warszawie, 10 V 1960 r.

ŻIH, TSKŻ, sygn. 325/149, [b.p.], Sprawozdanie, 19 VIII 1957 r.

ŻIH, TSKŻ, sygn. 325/149, [b.p.], Prezydium TSKŻ w Warszawie, 26 XI 1954 r.

ŻIH, TSKŻ, sygn. 325/154, [b.p.], Lista abonentów Fołks Sztyme (Głos Ludu) na I kwartał $1954 \mathrm{r}$.

ŻIH, Centralny Komitet Żydów w Polsce (dalej: CKŻP), Wydział Ewidencji i Statystyki, sygn. 303/VI/128, k. 20, Żydzi zarejestrowani wg zawodu i płci, czerwiec 1946.

ŻIH, CKŻP, Wydział Ewidencji i Statystyki, sygn. 303/VI/135, k. 87, Żydzi rejestrowani w miesiącu styczniu 1948 według zawodu i płci.

ŻIH, CKŻP, Wydział Produktywizacji, 303/XII/111, k. 12-12v., Eliasz Gołomb, Sprawozdanie z pobytu w Białymstoku od dnia 10 IX do 21 IX $1945 \mathrm{r}$.

ŻIH, Wojewódzki Komitet Żydowski w Białymstoku, sygn. 362/17, [b.p.], Do Związku Bojowników o Wolność i Demokrację Zarząd Okręgu w Białymstoku, 17.08.1950.

Archiwum Akt Nowych, Ministerstwo Gospodarki Komunalnej, sygn. 9/25, [b.p.], Wykaz żydowskich nieczynnych cmentarzy proponowanych do zamknięcia na terenie województwa białostockiego, 1963.

Archiwum Państwowe w Białymstoku (dalej: APB), Komitet Wojewódzki PZPR w Białymstoku (dalej: KW PZPR), sygn. 1368, k. 256-257, Rezolucja TSKŻ w Białymstoku, 18.03.1968.

APB, KW PZPR, sygn. 202, k. 166-169, Treść sprawy odwoławczej Soni Rogowskiej [XI 1968].

APB, KW PZPR, sygn. 1368, k. 258-259, Protokół nr 6/68, 18.03.1968.

APB, KW PZPR, sygn. 1415, k. 36, Informacja dot. sytuacji operacyjno-politycznej i nastrojów wśród społeczeństwa, 23.11.1967.

APB, KW PZPR, sygn. 1415, k. 43-44, Informacja, 7.02.1968.

APB, KW PZPR, sygn. 1415, k. 45, Do KW PZPR w Białymstoku, 14.05.1968.

APB, KW PZPR, sygn. 1415, k. 52-54, pismo J. Lesińskiego do KW PZPR, 25.04.1968.

APB, KW PZPR, sygn. 2146, k. 231, Protokół posiedzenia Prezydium Komisji Narodowościowej przy KW PZPR w Białymstoku, 10 X 1963.

Archiwum Instytutu Pamięci Narodowej (dalej: AIPN), sygn. IPN Bi 045/2, k. 289, Informacja $\mathrm{nr}$ 48, 27.04.1968 r.

AIPN, sygn. IPN Bi 045/2, k. 286, Informacja nr 46, 25.04.1968 r.

AIPN, sygn. IPN Bi 045/1680, k. 94, Meldunek dot. sytuacji w województwie w związku z konfliktem na Bliskim Wschodzie z dn. 8.06.67. 
AIPN, sygn. IPN Bi 045/2161, k. 71-72, Wykaz osób wrogo występujących i popierających agresję Izraela na kraje arabskie zarejestrowanych w ewidencji aktów wrogiej działalności przez jednostki operacyjne w 1967 roku, 22.03.1968.

AIPN, sygn. IPN Bi 93/3455/18, k. 9, Akta paszportowe: Bartnowski Szymon.

AIPN, sygn. IPN Bi 98/1776, Rogowska Sonia c. Mojżesza.

AIPN, sygn. Bi 045/2, k. 57, Meldunek, 17.03.1968 r.

AIPN, sygn. IPN Bi 127/8/2, k. 32, 36, 40, 44, 46, 54-76, 80, 82, 84-93, Wykaz nadesłanych spraw z jednostek paszportowych na wyjazd do KDL i KK [od 1 maja 1968 r. do 30 listopada 1970 r.].

AIPN, sygn. IPN Bi 127/8/2, k. 50, Zestawienie z wyjazdów czasowych i emigracyjnych do „KK” woj. białostockiego za $1967 \mathrm{r}$.

AIPN, sygn. IPN Bi 127/8/2, k. 78, Zestawienie liczbowe osób mniejszości narodowościowych ubiegających się o wyjazdy emigracyjne rok 1969.

AIPN, sygn. IPN Bi 127/31/2, Rejestr wydanych paszportów.

AIPN, sygn. IPN Bi 011/100, k. 59, Plan wykonawczy w sprawie obiektowej nr 11714/72 krypt. „Jafo” na 1982 r.

AIPN, sygn. IPN Bi 127/32/3, Rejestr spraw ubiegających się o wyjazd do państw kapitalistycznych za rok 1958/59.

AIPN, sygn. 1368, k. 73, Ocena sytuacji politycznej w wyższych uczelniach woj. białostockiego w okresie ostatnich wydarzeń, 8.04.1968.

\section{Strony internetowe}

http://baza.archiwa.gov.pl/sezam/sezam.php?l=pl\&mode=show\&zespoly $\mathrm{j} d=104740$

http://www.sztetl.org.pl/pl/article/bialystok/11,synagogi-domy-modlitwy-i-inne/381, boznica-cytronow-ul-warynskiego-24a-/

http://www.zchor.org/bialystok/toc.htm

http://www.zchor.org/bialystok/yizkor13.htm 